\title{
International Expansion: A Case Study Of Mongolia's Dairy Market
}

Shelly A. Daly, Lindenwood University, USA

Tsogt Ganbold, Lindenwood University, USA

\begin{abstract}
A businessman teaches himself the fundamentals of business and marketing in order to expand beyond the region of his Mongolian home. He must work through the meaning of supply and demand and customer-orientation which are foreign concepts to him. Letting go of the fundamental principles taught to him by a socialist system and competing in the $21^{\text {st }}$ century may bring success, but first he must identify the challenges and begin to understand which ones are significant to overcome for success.
\end{abstract}

Keywords: Case Study; Emerging Markets; Marketing; Mongolia; Entrepreneur

\section{INTRODUCTION}

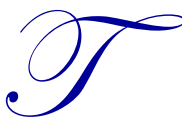

here exists a country of abundant landmass and unspoiled terrain that has a rich history of culture, learning and conquests. It covers over 600,000 square miles and has a population of 2.7 million, $59 \%$ of which is under the age of 30 . Its landmass is similar in size to Iran and Indonesia and slightly smaller than that of Mexico. By comparison, those countries have a population of 75 million, 240 million, and 112 million, respectively. The population was well-educated under the socialist era prior to the 1990s and this trend continues today. It is a country rarely mentioned in literature or discussions of emerging markets or transition economies. Nevertheless, Mongolia is both.

While Mongolia's transition from socialist underpinnings has taken place outside of the glaring media coverage and center stage that other transitional economies have experienced, it has transitioned and changed and realigned its business practices and ideologies. Observers may easily believe that the transition was seamless and relatively painless for the average citizen and business. By comparison to larger countries at the forefront of media attention and research focus, this would be true. However, upon closer examination, the next generation of business success stories has a unique and intriguing environment to explore, learn, and master.

\section{SETTING}

One of the most important elements of the Mongolian diet is referred to as 'white foods'. These white foods are processed dairy products made from the milk of horses, camels and sheep. Milk is the main ingredient in food for most of the year and traditionally the main diet for the six months of summer. Over 2,000 traditional dishes contain milk as the main ingredient in Mongolian meals. During the six months of winter, the diet contains a higher abundance of meat products, but the white foods still play an integral role for nutrition and health. Thus, the Mongolian people have a long and sound tradition, methodology and technique for processing and using milk products. These white foods are generally categorized into three main categories of protein-rich, sour products and oily products. The dairy products include clotted cream, diary fat, various types of milk curds, milk, fruit yogurt, fermented dairy beverages, cheese and distilled alcoholic spirits.

Anareekem Gansabold is a successful entrepreneur in a dairy product business in Mongolia. Anar is inventive and a risk-taker and desires to grow his company in a way that many people have said will not work. He wants to introduce the traditional Mongolian white foods into new cultures. 
Anar has considered the roadblocks for his expansion idea. First and foremost is that he has no formal business training or education. He grew up under the communist system that was not controlled by demand and supply. Marketing was nonexistent and, until very recently, he had never heard of or considered the four traditional underpinnings of marketing called the four P's. He was very focused on thinking about the price, product, place, and promotion for his company's expansion but was not sure he had the expertise or knew anyone else that could assist him with these marketing tenants.

Although he considered his lack of business expertise as the biggest roadblock to this type of business expansion, Anar knew that eating white foods was an acquired taste unique in Mongolia. He felt that outsiders would consider any food or dairy products from Mongolia to be less desirable than food from almost anywhere else. He had been told that Europeans and Americans would never think of eating camel or horse milk.

Additionally, being a small dairy operation meant that it was very important for Anar to nurture his domestic business and sales in order to help subsidize his expansion. Like most small business owners and managers, he had to proficiently manage his resources in an attempt to achieve stability and consistency at home while treating the foreign market as a secondary aspect of doing business. Resources such as skilled labor, processing equipment, raw milk, and capital were all in short supply. Anar could not afford to make mistakes and waste supplies or money or frustrate his employees who did not see the need or have the desire to expand.

\section{EXPANDING？THE FUTURE}

Anar was used to taking risks and was comfortable with risk in a way that marked him as unique and entrepreneurial when compared to many of his peers. In the mid to late 1990's, just setting up the shop in UlanBator where he would sell traditional Mongolian style white foods was a considered very enterprising. Local shops were previously dominated by Russian products and foods. Traditional Mongolian white foods were usually prepared at home for family use only. His shop quickly grew in notoriety with locals and was a favorite shopping place. Fifteen years later, he had ten small shops in Mongolia and five in Russia. Additionally, his products were available at the biggest grocery stores in 20 Mongolian provinces. He also opened a home delivery service which is considered very unique and innovative in Mongolia.

His customer base was still primarily Mongolian. The home delivery option helped Anar to learn much about looking at his customers' needs and wants in deciding how to stock shops in various areas and which products to offer for home delivery. He was intrigued by this aspect of marketing and enjoyed analyzing his sales to grasp better ideas for responding to the customer. However, he was still uncertain about how to best use the sales numbers or how to process the data to get the most out of the information at hand.

One night in 2011, Anar decided to begin writing down his plans and to finally pursue the idea that had been in his thoughts for some time. He wanted to introduce more of the world to his dairy products. He felt his biggest asset at this time was his brand identity. He had not even meant to develop the brand when his domestic expansion began, but realized now that this was very positive and a definite business strength for him. Secondly, he felt his desire to be customer-oriented would serve him well as he expanded. His attention to the sales records for the home delivery service had given him an awareness of the need to pay attention to what customers wanted. This was very different from the Soviet system where supply did not reflect demand. Under that way of doing business, supply reflected non-market forces and customers never knew what products might be available or when. Although both of these assets came about almost accidentally, Anar wanted to proceed very purposefully into the next aspect of his business expansion.

Cost reduction, production efficiency and business-to-business relationships were the three areas that Anar felt would be important to further expansion outside of Mongolia. However, as he identified these three areas, he was very aware that his business expertise was limited and he had no formal education or training in business knowhow or practices. He had developed good administrative capabilities during his years in business. This in itself left him in a predicament. For him to expand, he would need to delegate the administrative side of the business to someone else and he was not sure if any of his current employees were interested or capable in this task. It also represented a vital aspect of his success in that he had developed excellent and strong relationships with milk 
suppliers, employees, dealers, restaurant owners, and distributors. The idea of jeopardizing any of these links in his domestic chain of business caused him many sleepless nights.

A few other factors made it onto Anar's list of important business considerations. He had started a specific line of white foods products that were sold as health foods. These were in response to citizen requests and were sold in his three Russian markets of Irkutsk, Saint Petersburg, and Ulan-Ude. He thought there may be a similar demand for such health foods in other cultures. His local Mongolian dairy farmers had provided invaluable experience and knowledge about how to process the milk and the various products that could be produced. Finally, the technology available in 2011 meant that product shipment could occur the same day as manufacturing to ensure the highest level of quality and freshness.

A final factor was Anar's relationship with his employees. He treated them well, acknowledged them often with praise and small rewards, and gave them extra benefits whenever possible. Also, by extension, he gave encouragement, kind words and fun contests to the employees of his distributors in order to make them feel appreciated and valued. He also helped the farmers in any way he could. If there was new equipment or feed available, he would help pay for a class for them to learn of this new opportunity.

Anar wanted his company's success to feed back into the community of Ulan Bator, Mongolia's capital and his home city. He was not sure how this could happen but wanted this link to be established before he began to expand internationally. He had thought about this idea for a couple of years but was uncertain where to go with it. He definitely needed direction for this aspect of his business planning.

Anar also wondered if he should cut back on any aspect of his current business operations in order to be better prepared for expansion. His personal viewpoint was that stable growth was a result of managing relationships with suppliers, employees, retailers, and consumers. He wondered if his current relationships would be negatively impacted if he decreased current business sales in lieu of foreign expansion. Was there a way to do both and not anger existing customers or distributors?

\section{CONCLUDING REMARKS}

After committing all of these thoughts to paper, Anar called it a night. He was not sure what the next step would be but was confident that it was time to take the risk on expansion. Tomorrow he would begin to think about where to expand and how to obtain more direction with his business planning. For now, he wanted to keep his plans very confidential, but at the same time, he needed help to develop the plan and timeline. He hoped that his patience, experience, and careful planning would help him identify where to turn for help and direction and make international expansion a reality in 2012 .

\section{DISCUSSION QUESTIONS}

1. When Anar identified the three items that were important for him to expand outside of Mongolia, had he developed a comprehensive list? Were these the most important items? Were there other items that were more important than these three?

2. What are some alternatives to Anar's predicament with delegating administrative duties in order to concentrate on his new expansion ideas?

3. The case states: "Anar wanted his company's success to feed back into the community of Ulan Bator, Mongolia's capital and his home city." What does this mean and how could it be actualized?

4. Should international expansion require any cutbacks in Anar's current business? Why or why not?

5. Where should Anar expand? What markets offer the best opportunity? Should he concentrate on other former soviet bloc countries?

\section{AUTHOR INFORMATION}

Dr. S. Daly is an Assistant Professor of Business at Lindenwood University in St. Charles, Missouri. Dr. Daly has worked and lived in several Eastern European countries, was awarded an AACSB fellowship, and spent almost a 
decade in the aerospace industry. Lindenwood University, 209 South Kingshighway, Harmon Hall 155, St. Charles, MO 63301, 639-949-4902. E-mail: sdaly@lindenwood.edu (Corresponding author)

Mr. Tsogt Ganbold lives and works in Mongolia. He is a graduate of Lindenwood University with a Master of Business Administration. E-mail: tsogt@myway.com 